\title{
THE STRUCTURE OF THE STOMATA OF CERTAIN CRETACEOUS CONIFERS ${ }^{x}$
}

\author{
W. P. THоMPSON \\ (WITH PLATES V AND VI)
}

The structure of the stoma is remarkably uniform in all members of the plant kingdom, from Anthoceros to the highest angiosperms. It consists essentially of an aperture surrounded by two guard cells which may be more or less sunken and protected by adjacent cells. The only deviation from this organization has been described for the fossil genus Frenelopsis, first by ZEILLER, ${ }^{2}$ and more recently by BERRY. ${ }^{3}$ These authors state that in place of the usual two guard cells, each stoma of Frenelopsis is surrounded by four or five guard cells in the form of a rosette. The uniqueness of this supposed condition made it desirable that the subject should be reinvestigated, and for this purpose I have had access to material of Frenelopsis occidentalis (Heer), supplied by Professor ZeILler from a collection made at Nazareth, Portugal, by Professor Choffat.

The characters of the genus Frenelopsis have been given in detail by Ettingshausen, ${ }^{4}$ SCHenK, ${ }^{5}$ and others. It is a cretaceous conifer of disputed affinities, being referred by some authors to the Cupressineae and by others to the Gnetales. The leaves are decussately arranged in twos or fours at the nodes of the jointed stem. They are reduced, squamiform, and appressed. The internodes functioned as leaves.

The epidermal characters of Frenelopsis occidentalis have been No. 45 .

${ }^{x}$ Contributions from the Phanerogamic Laboratory of Harvard University,

${ }^{2}$ Zeiller, R., Observations sur quelques cuticules fossiles. Ann. Sci. Nat. Bot. 6: $1_{3}$. 1882 .

${ }^{3}$ BERRY, E. W., The epidermal characters of Frenelopsis ramosissima. Bot. GAz. 50:305-309. figs 2. 1910.

${ }^{4}$ Ettingshausen, C., Abhand. k.k. geol. Reichsanstalt. Vol. I.

${ }^{5}$ Schenk, H., Palaeontogr. I9: $13 .-$ 
described by ZeILLER. ${ }^{6}$ The cells are rather small, roughly rectangular, and very thick-walled. The very numerous stomata are arranged in irregular lines which give a striated appearance to the unmagnified specimen.

A single stoma is shown in surface view in fig. I. The central aperture is surrounded by the five "guard" cells of BERRY and ZEILler. A conical projection can be distinguished extending from each cell to the common center and together forming the rosette. These projections are really below the surface, and, since they are in focus, the opening at the surface is indistinctly seen above them as a pentagonal area whose walls coincide with the bases of the cones.

A clearer idea of the relation of the parts may be obtained from fig. 2, which is a photograph of a vertical section through one of the stomata. The conical processes of the so-called "guard" cells are here seen to project into the middle of a cavity. At the upper limit of this cavity, that is, at the surface, the epidermal cells again approach each other to form, not conical projections, but the pentagonal opening seen indistinctly in the photograph of the surface. These complicated cells are regarded by both BERRY and ZEILLER as guard cells, obviously unlike the guard cells found anywhere else in the plant kingdom. ZeILLER compares them with those of Marchantia as follows:

Le seul fait qui me semble avoir quelque analogie avec cette constitution particulière des stomates, serait celui qu'on observe chez les Marchantiées, où les pores stomatiques sont bordés par cinq ou six cellules, mais qui laissent entre elles une ouverture en forme de canal, et non pas une fente en étoile, comme dans l'espèce dont je viens de parler. Il serait cependant assez singulier et assez peu vraisemblable que cette forme étoilée des stomates fût un fait isolé, n'existant que chez le seul Frenelopsis Hoheneggeri, et peut-être faut-il s'attendre à la retrouver quelque jour sur d'autres plantes fossiles, sinon même dans la nature vivante.

In his conception of their arrangement, BERRY disregards that part of the cell above the diverticulum, although he figures it in his low-power drawing. ${ }^{7}$ Aside from their unique number and disposi-

${ }^{6}$ Zeiller, R., Elements de palaeobotanique. Paris. Ig00.

${ }^{7}$ Loc. cit., p. 307 . 
tion, it is difficult to imagine how these structures could effectually serve as guard cells.

The proper conception of the arrangement and homologies of these parts may be most easily obtained from an examination of living forms. The conditions existing in Agathis bornensis are represented in fig. 6, which is a photograph of a vertical section of the base of the leaf of that species. The two conspicuous oval cells almost in contact are the sunken guard cells. Inclined above them, with their small extremities at the strongly cutinized surface, are the accessory cells. Each of the latter is seen to have a slight projection into the cavity some distance above the guard cells. Viewed from the surface (fig. 7), the accessory cells are seen to be four in number surrounding the opening. From the same viewpoint, the guard cells (fig. 8) are seen to be two in number, and arranged in the usual manner.

These conditions at once suggest that the so-called guard cells of Frenelopsis are really accessory cells, and that we must look below them for the true guard cells. As stated by both BERRY and ZEILler, structural material of the epidermis only is available, so that the depressed guard cells are not likely to have been preserved. Nevertheless, diligent search reveals their presence in many favorable specimens. Fig. 3, which is a photograph of another stoma in section, shows two well-preserved guard cells at the bottom of the cavity into which the conical structures project. Fig. 4 shows another stoma with unmistakable guard cells below the accessory cells. In this figure the end of a projection from another accessory cell has been cut off and appears in the center of the stomatic cavity. In the majority of the stomata examined in section, no guard cells can be distinguished; in others, fragments have been preserved, especially the outermost wall, which appears to have been more strongly lignified; in still others, the whole structure is preserved in exactly the relations which one would expect in living material.

It is still more difficult to observe the guard cells in surface view, owing to the fact that they are covered by the extremely thick accessory cells. This circumstance also entirely precludes their reproduction by photograph. Nevertheless, examination of the 
epidermis from beneath reveals their presence in a condition of good preservation in some instances, and of imperfect preservation in many others. A camera lucida drawing showing their typical arrangement above the accessory cells (below in nature) is presented in fig. 5. They are seen to have the normal form. The thinness of their walls probably accounts for the imperfect state of preservation.

That true guard cells of the normal form are present in Frenelopsis, in addition to the remarkable accessory cells, is further indicated by the similar conditions presented by other cretaceous plants. A case in point is furnished by Androvettia statenensis Hollick and Jeffrey. Fig. 9 is a photograph showing the general features of the epidermis of the species. The cells are very thickwalled and irregular in shape. The numerous stomata lack the definite arrangement characteristic of Frenelopsis. The more highly magnified representation given in fig. Io shows the presence of accessory cells around the stomata as before. In this case they lack the conical projections of Frenelopsis, the opening having a uniform outline. The presence of true guard cells is strikingly illustrated in the figure, the aperture appearing as a conspicuous slit across the space surrounded by the accessory cells. Owing to the good condition of preservation of this plant, the guard cells are distinguishable in the majority of cases. Nevertheless, in poorly preserved specimens they have often been destroyed just as in Frenelopsis. Fig. I I shows two stomata from which the guard cells have completely disappeared, although the accessory cells are present in their normal condition.

Another cretaceous fossil possessing both true guard cells and accessory cells is Brachyphyllum macrocarpum Newberry. A section parallel to the surface of the leaf of this plant is shown in fig. I2. In each of the stomata the two guard cells are seen to be surrounded by four accessory cells.

The evidence herein adduced from the structure of the stomata of modern conifers, from the conditions presented in fossils of the same geologic age, and above all from actual observations both in section and surface views of Frenelopsis itself, appears to show conclusively that true guard cells are present in this genus, and that the 

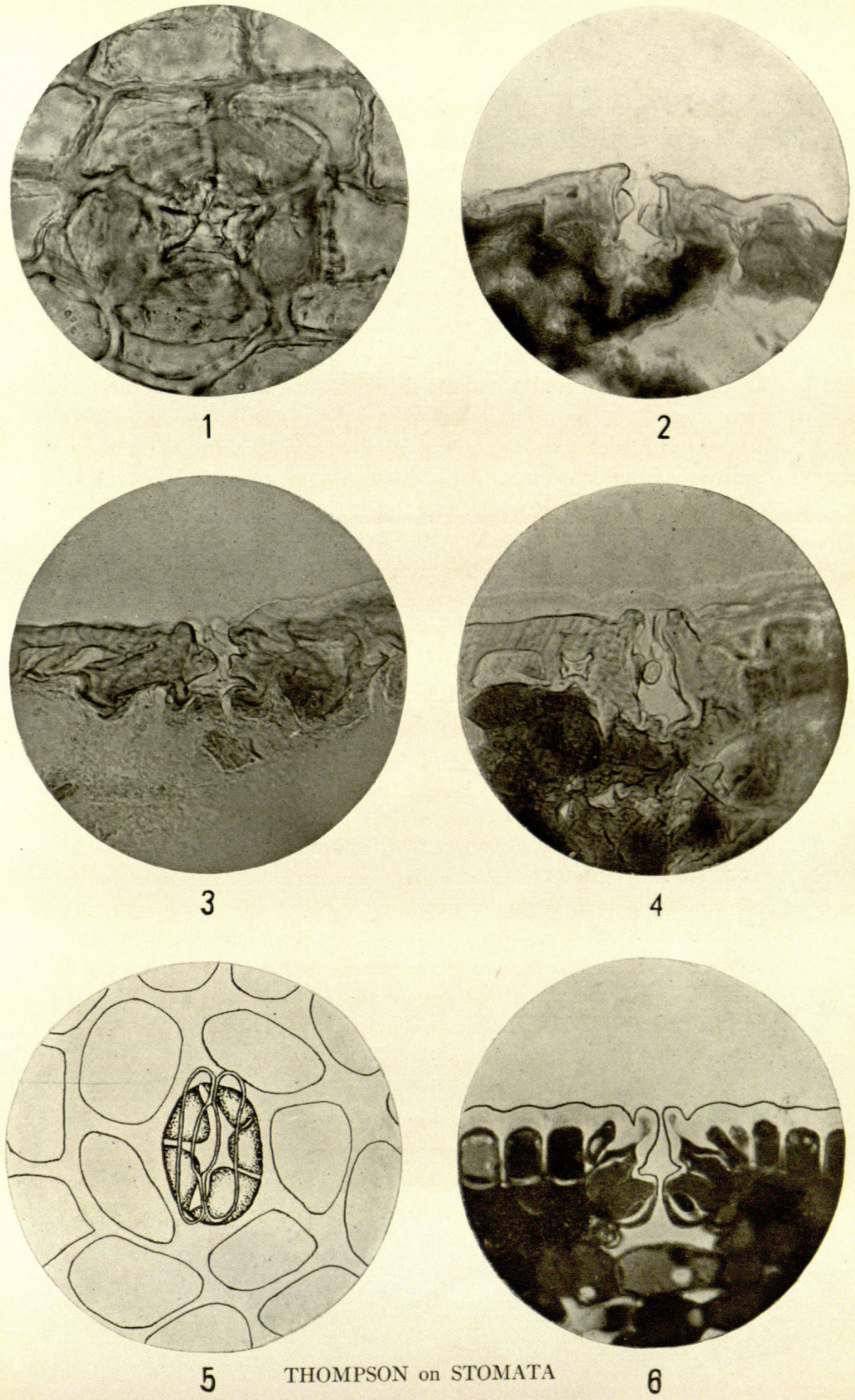

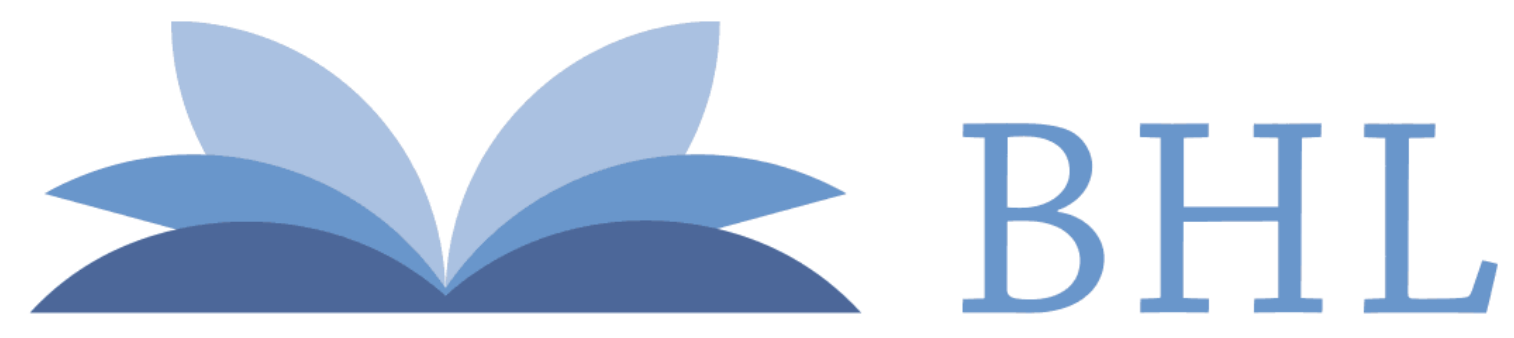

\section{Biodiversity Heritage Library}

1912. "The Structure of the Stomata of Certain Cretaceous Conifers." Botanical gazette 54(1), 63-67. https://doi.org/10.1086/330864.

View This Item Online: https://www.biodiversitylibrary.org/item/109452

DOI: https://doi.org/10.1086/330864

Permalink: https://www.biodiversitylibrary.org/partpdf/223470

\section{Holding Institution}

Missouri Botanical Garden, Peter H. Raven Library

\section{Sponsored by}

Missouri Botanical Garden

\section{Copyright \& Reuse}

Copyright Status: Public domain. The BHL considers that this work is no longer under copyright protection.

This document was created from content at the Biodiversity Heritage Library, the world's largest open access digital library for biodiversity literature and archives. Visit BHL at https://www.biodiversitylibrary.org. 